\title{
PROPEDÊUTICA À TEORIA DA HISTÓRIA
}

Francisco R. Rüdiger*

A renovação das disputas sobre a natureza da razão histórica provocada pelo movimento do pós-modernismo motiva-nos a empreender um trabalho de esclarecimento dos pressupostos conceituais que embasam a discussão acadêmica sobre a "teoria" da história.

Permita-se-nos realizar essa tarefa sob a forma de teses.

1. A palavra história designa tanto uma disciplina cientifica quanto sua matéria de conhecimento. O segundo sentido refere-se aos processos sociais em seu devir, enquanto o primeiro remete ao seu estudo metódico, aos seus procedimentos de investigação. A expressão teoria da história carrega consigo essa ambigüidade, na medida em que pode se referir tanto a um conjunto de hipóteses sobre a estrutura e sentido de determinados processos sociais (historicidade), quanto à reflexão conceitual sobre o saber histórico (historiografia). O território da reflexão teórica sobre os fundamentos e natureza dos estudos históricos corresponde ao que conviria denominar mais corretamente de epistemologia da história; isto é, à pesquisa, estudo e análise da estrutura lógica e conceitual (metodologia) através da qual se produz o conhecimento histórico, através da qual se elabora uma historiografia. Conseqüentemente caberia reservar à expressão teoria da história a designação de o conjunto de conceitos através dos quais os historiadores procedem à interpretação e análise do seu campo de pesquisa.

* Professor-Adjunto da Pontificia Universidade Católica e Universidade Federal do Rio Grande do Sul. Mestre em Filosofia (UFRGS), Doutor em Ciências Sociais (USP). Publicou Paradigmas do Estudo da História (Porto Alegre, IEL/IGEL, 1991).

Estudos Ibero-Americanos. PUCRS, v. XXIII, n. 1, p. 155-159, junho, 1997 
2. A epistemologia da história, chamada também de filosofia analítica da história, ou ainda crítica da razão histórica, constitui uma disciplina filosófica: representa uma metalinguagem, cujo objeto é a ciência da história. As concepções ou "teorias" da história, ao contrário, tratam, consciente ou inconscientemente, do processo histórico enquanto terreno da pesquisa empirica do historiador. Exemplificando, a hermenêutica filosófica é um paradigma de compreensão do conhecimento histórico; o materialismo histórico é uma concepção ou teoria da história.

3. A epistemologia do conhecimento histórico e as concepções teóricas do processo histórico (doravante chamadas simplesmente de teorias da história) devem ser distinguidas formalmente das filosofias da história. As filosofias da história se referem ao processo histórico em sua totalidade, distinguindo-se das teorias na medida em que, ao contrário dessas, ultrapassam o terreno da pesquisa empírica e, assim, procuram determinar o sentido global da história. Na investigação empírica, o referencial teórico constitui basicamente uma hipótese que, embora possa se projetar para todo o processo histórico, é empregada para explicar os acontecimentos determinados empiricamente pelo historiador. Na filosofia especulativa, a reflexão teórica sobre o transcurso do processo histórico tem uma pretensão de certeza ontológica. A pesquisa julga-se mais ou menos capaz de desvendar, senão o sentido, ao menos os padrões ou leis que regem o conjunto (passado e futuro) da história.

4. A epistemologia da história não é uma disciplina consensual, encontra-se dividida, desde que surgiu, em diversos paradigmas ou modelos de compreensão da natureza gnoseológica e estrutura lógica do conhecimento histórico. O desenvolvimento desses paradigmas é correlato ao progresso dos estudos históricos, mas também do pensamento filosófico, conservando uma certa autonomia. A relação entre a disciplina e estes estudos, por isso mesmo, não deve ser vista de maneira mecânica, como se os modelos que se constroem através dela fossem simples reflexo teórico do trabalho dos historiadores. Os condicionamentos entre ambos são mútuos, mas marcados por mal-entendidos.

5. A historiografia pressupõe uma fundamentação epistemológica, embora seus praticantes costumem rechaçar as definições que esta lhes em- 
presta. Os paradigmas carregam consigo pretensões normativas, contêm proposições programáticas, resultantes do fato de provirem, antes de mais nada, da reelaboração filosófica dos métodos e técnicas empregados na pesquisa histórica, quando não de uma reflexão autônoma que, a despeito de suas pretensões utilitárias, revela-se bastante distante da práxis historiográfica. Destarte, as concepções teóricas que formulam devem ser vistas sobretudo como instâncias de reflexão, patamares reflexivos onde os praticantes e interessados no saber histórico eventualmente podem esclarecer seus procedimentos e a historiografia eventualmente pode desenvolver a consciência de sua natureza como conhecimento.

6. A epistemologia da história, considerada em sentido pragmático, é uma disciplina analítica e interpretativa. Os paradigmas não entretêm relação direta com os estudos históricos. Inversamente, a historiografia não se estrutura puramente conforme suas prescrições. Os historiadores conduzem seu trabalho segundo preceitos de natureza variada, dependentes, consciente ou inconscientemente, de diversos entendimentos. Exemplificando, 0 Escravismo Colonial (Jacob Gorender) enquadra-se no referencial gnoseológico estruturalista (trabalhando com o materialismo histórico no plano da teoria da história). Já $O$ Combate nas Trevas, do mesmo autor, enquadra-se no referencial historicista (trabalhando com uma concepção pragmática do processo histórico).

7. Os paradigmas de compreensão do saber histórico não são uma espécie de reflexo teórico desse saber, nem podem ser aplicados praticamente. A serventia prática dos mesmos se encontra no esclarecimento e análise da estrutura gnoseológica e dos métodos de pesquisa e exposição do conhecimento histórico presentes na historiografia. Aparentemente classificatórios, os paradigmas constituem antes de mais nada um instrumento analítico, dependente de estudos concretos, realizados caso a caso e, por princípio, avessos às deduções apriorísticas. Noutros termos, representam conceitos críticos, que precisam ser usados criativamente, mas com os quais podemos nos aparelhar para melhor julgar os limites do texto histórico e a envergadura de uma historiografia.

8. A epistemologia da história implica um trabalho de análise lógica do saber, que remete às seguintes instâncias de reflexão (estágios de leitura do texto histórico): 
a) epistemológica: concentra-se na análise da modalidade de conhecimento do objeto histórico (gnoseologia) sustentada pela investigação; particularmente na determinação conceitual (estruturalista, hermenêutica etc.) da abordagem do mundo histórico feita pelo historiador.

b) intelectual: verifica se a investigação se enquadra num programa de pesquisa coletivo ou individual; particularmente se é coerente com suas propostas e contribui para o progresso de seu desenvolvimento.

c) histórica: verifica se a pesquisa desenvolveu a consciência de sua pertença a um contexto histórico, detendo-se sobretudo na maneira como essa consciência se transforma em princípio heurístico de construção do objeto.

d) teórica: procede à analise dos sistemas de conceitos empregados pelo historiador, visando entender a coerência e limites da sua respectiva abordagem.

e) metodológica: concentra-se na análise das estratégias de investigação documental e modalidades de construção (textual) do mundo histórico empregadas pelo pesquisador; particularmente dos procedimentos explicativos e estruturas argumentativas (conexões históricas) do objeto da construção historiográfica.

f) técnica: examina as técnicas de pesquisa, o manejo das fontes e as formas de exposição do material investigado.

g) "empirica": considera a propriedade da delimitação do terreno de pesquisa ("determinação do objeto") realizada pelo investigador.

Conviria observar ainda que, comumente, as referidas instâncias funcionam como estágios de reflexão cujo sentido varia conforme se tem uma postura de teórico ou de historiador. Enquanto o historiador tende a proceder de maneira indutiva, partindo do empírico para o gnoseológico, o investigador teórico procede de maneira dedutiva, da epistemologia para o plano do objeto.

9. O trabalho de análise lógica indicado no tópico anterior, entendido de maneira devida, virtualmente funciona tanto como instância de vigilância crítica contra os preconceitos ideológicos e de esclarecimento epistêmico na produção do saber, quanto de esquema dos estágios de leitura crítica do texto histórico. As perspectivas se colocam conforme nos situamos no ponto de vista da produção ou da recepção dos estudos históricos. 
10. O desenvolvimento dos estudos históricos dificilmente pode ser descrito como um processo de emprego sistemático e racional das proposições produzidas pela reflexão teórica sobre a natureza conceitual e a estrutura lógica da práxis historiográfica (epistemologia). Entretanto, podemos defender a hipótese de que se a reflexão que se faz nesse sentido passasse, de maneira orgânica, a ser parte do esforço cognitivo dos historiadores haveria bons motivos para superar a constatação de que os prejuízos que decorrem de sua falta "provêm do fato de que as investigações autorizadas sobre esta importante matéria [a metodologia da história] não foram realizadas pelos historiadores, nem pelos teóricos da história, mas por representantes de disciplinas muito distantes" (Weber).

\section{REFERÊNCIAS BIBLIOGRÁFICAS}

HELLER, Agnes. Teoria de la história. Barcelona: Fontamara, 1980.

RÜSEN, Jörn. Grundzüge einer Historik I: Historische Vernunft. Göttingen: Vandenhoeck und Ruprecht, 1973.

WEBER, Max. Metodologia das ciências sociais. São Paulo: Cortez; Campinas: Unicamp, 1992. 